Article

\title{
Built to Sustain: The Effect of Entrepreneurial Decision-Making Logic on New Venture Sustainability
}

\author{
Dan Long *, Houhong Wang and Peili Wang
}

check for updates

Citation: Long, D.; Wang, H.; Wang, P. Built to Sustain: The Effect of Entrepreneurial Decision-Making Logic on New Venture Sustainability. Sustainability 2021, 13, 2170.

https://doi.org/10.3390/su13042170

Academic Editor: Ladislav Mura

Received: 28 January 2021

Accepted: 12 February 2021

Published: 18 February 2021

Publisher's Note: MDPI stays neutral with regard to jurisdictional claims in published maps and institutional affiliations.

Copyright: (c) 2021 by the authors. Licensee MDPI, Basel, Switzerland. This article is an open access article distributed under the terms and conditions of the Creative Commons Attribution (CC BY) license (https:// creativecommons.org/licenses/by/ $4.0 /)$.
School of Management, Hefei University of Technology, Hefei 230009, China; 17715051926@163.com (H.W.); pallywang@163.com (P.W.)

* Correspondence: longdan@hfut.edu.cn

\begin{abstract}
How entrepreneurs make entrepreneurial decisions to improve entrepreneurial performance is a popular concern in both theoretical and practical circles. Existing studies mostly analyze the effect of entrepreneurial decision-making logic on the survival and growth of new ventures from the perspective of financial performance, but few studies focus on new venture sustainability. Based on datasets from the first two survey rounds of CPSED (Chinese Panel Study of Entrepreneurial Dynamics), this paper selects a group of 259 entrepreneurs as a sample and uses logistic regression analysis as a research method. The purpose of this study is to examine the effects of entrepreneurial decision-making logic on new venture sustainability. There are two main entrepreneurial logics, namely effectuation and causation. The paper discusses causation in terms of four dimensions, namely goal orientation, expected returns, competitive analysis, and avoiding contingencies. It examines effectuation in terms of the dimensions of means orientation, affordable loss, partnerships, and leveraging contingencies. The empirical results show that goal orientation plays a negative role in promoting new venture sustainability, while avoiding contingencies has a positive influence on it. Partnerships are conducive to new venture sustainability, while means orientation and leveraging contingencies have a negative effect.
\end{abstract}

Keywords: entrepreneurial decision-making logic; causation; effectuation; new venture sustainability; Chinese Panel Study of Entrepreneurial Dynamics

\section{Introduction}

Entrepreneurship is a dynamic, complex process that involves taking a series of entrepreneurial actions to obtain external resources, exploit identified opportunities, and then ultimately, create a new venture [1,2]. According to CPSED (Chinese Panel Study of Entrepreneurial Dynamics), the prevalence of nascent entrepreneurship in China is $4.77 \%$, indicating that nearly five out of every hundred adults in China are involved in starting new firms. In the initial CPSED dataset, there were 321 nascent entrepreneurs (individuals who had initiated entrepreneurship but who had not yet been successful in creating a new venture). In the second wave of follow-up interviews, only 29 of these individuals (about 9\%) had accomplished the preparatory process and entered business operation.

One of the most important reasons for this mismatch between nascent entrepreneurship prevalence and entrepreneurial success rate is entrepreneurial decision making [3]. Entrepreneurs are required to make numerous decisions including opportunity identification, resource acquisition, team composition, etc. Any decision-making mistake can cause the startup to fail. Entrepreneurial decision making plays a crucial role in entrepreneurial outcomes [4].

How entrepreneurs make entrepreneurial decisions to improve entrepreneurial performance is, therefore, an increasingly important concern in both theoretical and practical circles. Traditional management decision theory is based on a stable market environment and is goal-driven and prediction-based. It usually adopts causation to solve decisionmaking problems in the enterprise management process and maximize expected returns. 
However, in the context of entrepreneurship, most new ventures lack resources, reputation, corporate culture, etc. They may face challenges such as immature industries or markets with typical Knightian uncertainty [5]. In this context, it is difficult for classical management decision theory to play a role.

However, based on Simon's bounded rationality behavior theory, Sarasvathy proposes the concept of "effectuation", which is more applicable to the entrepreneurial context. Effectuation punctures some of the assumptions of traditional economics and management [6]. Entrepreneurs who employ effectuation are concerned with the various possible results brought by the integration of existing means and resources. They choose a satisfactory result from these possibilities. Effectuation does not emphasize accurate predictions of the future. Since effectuation was proposed as a concept, it has been popular with scholars, many of whom believe that it not only highlights the uniqueness of the entrepreneurial context but also provides a unique perspective for academic contributions to entrepreneurial research $[7,8]$.

Research on entrepreneurial decision-making logic, which is composed of causation and effectuation, has flourished. In the early days, scholars focused on theoretical analysis, exploring the differences and measurement of effectuation and causation [6,9-11]. Since 2008, some scholars have carried out empirical research and case studies to analyze the effects of entrepreneurial decision-making logic on entrepreneurial performance [12-14].

However, few studies examined the effects of entrepreneurial decision-making logic on new venture sustainability. Most of the existing research focused on the survival and growth of new ventures from the perspective of financial performance [15,16]. A high level of new venture sustainability not only means that new ventures can make long-term profits in a fierce market environment; it also helps to alleviate employment problems, accelerate social progress, and promote the steady development of the national economy. This paper aims to explore the effects of entrepreneurial decision-making logic on new venture sustainability, which can enrich the research on entrepreneurial outcomes related to entrepreneurial decision-making logic and cover the shortage of new venture sustainability studies in terms of entrepreneurial decision-making logic.

In addition, in previous research on the outcomes of entrepreneurial decision-making logic, few scholars comparatively analyzed the influence of causation and effectuation in the same context. This study comparatively analyzes the effects of causation and effectuation on new venture sustainability, enriching differentiated research on the outcomes of entrepreneurial decision-making logic.

It is worth noting that existing studies, due to data restrictions, often adopt retrospective data to examine entrepreneurial decision-making logic from a static perspective. Such studies ignore the dynamic evolution of entrepreneurial decision-making logic and the time lag that affects entrepreneurial results, restricting the accuracy of research conclusions [17]. This paper uses Chinese Panel Study of Entrepreneurial Dynamics data to deal with it.

This article is structured as follows. First, we review the relevant literature. Second, hypotheses are proposed. Third, we introduce our data source, sample screening criteria, and measures of related variables. Fourth, we carry out empirical analysis to test the hypotheses. Finally, we summarize our findings, discuss the contributions and limitations of the study, and suggest some directions for future research.

\section{Literature Review}

\subsection{Entrepreneurial Decision-Making Logic}

In "Causation and Effectuation: Toward A Theoretical Shift from Economic Inevitability to Entrepreneurial Contingency", Sarasvathy [6] points out that causation and effectuation are the two main types of entrepreneurial decision-making logic.

"Causation" was originally proposed by the philosopher and logician Burks in 1977 [18]. Later, it was introduced into the fields of economics and management to describe entrepreneurial decision-making logic. Before the 1980s, when managers made decisions, they usually faced a relatively stable environment, and their attention focused on how 
to achieve enterprise goals and maximize profits. Correspondingly, the decision-making method advocated by classical management theory is also based on the premises that decision makers are rational, information can be obtained, and the future can be predicted. Rational choices can be made among multiple decision-making schemes, so as to determine the best scheme to achieve given goals [6]. Sarasvathy uses "causation" to describe this decision-making method.

Causation is a prediction-based decision model (see Figure 1). Its decision-making process is as follows. First, decision makers need to identify entrepreneurial opportunities that may develop into new products, new companies, or new markets in the current environment. Second, through competition analysis and market research, decision makers should examine consumer demand. According to the results of their survey, they must subdivide the existing market, determine the target market, and develop business plans. Third, based on the goals in their business plan, they should obtain the necessary resources and connect with stakeholders to promote their entrepreneurial process. Finally, in order to maintain their competitive advantage, decision makers need to constantly adjust means to dynamically adapt to environmental changes in this process [6].

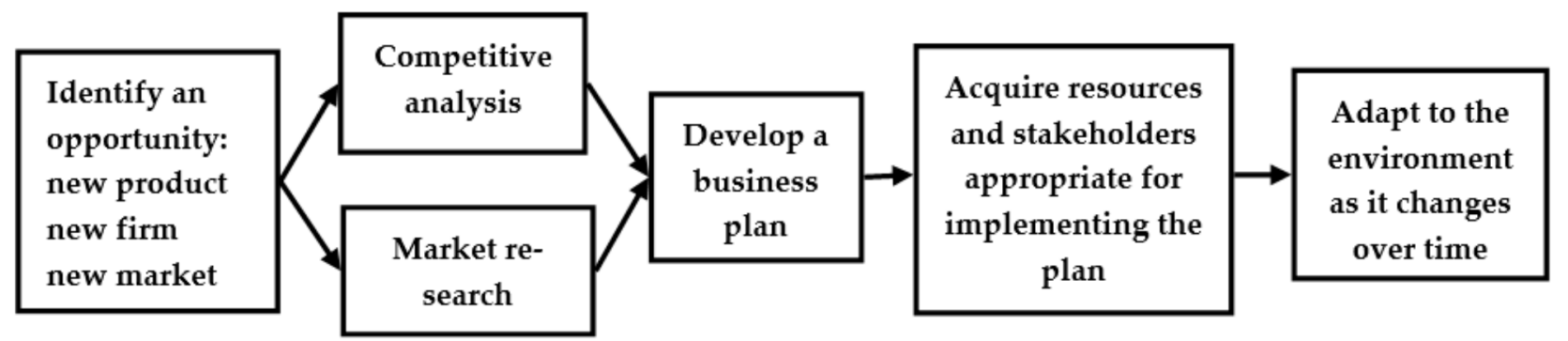

Figure 1. The model of causation.

"Effectuation" was first proposed by James in 1912. The interpretation given in the Oxford Advanced Dictionary is "the expected result produced by an event rather than a person". Later, the concept was creatively introduced into the field of management by Sarasvathy. Effectuation breaks the basic assumptions of mainstream economics and management, proposing new assumptions that are more in line with the objective reality of decision making. The differences between these two sets of assumptions are mainly reflected in the actors and environment. On the one hand, mainstream economics assumes that actors equate to the "economic man"; that is, the goals and behaviors of actors are assumed to be rational, in pursuit of the greatest material benefits. However, the actor assumption proposed by Sarasvathy, which evolved from Simon's "bounded rationality assumption", suggests that actors pursue the most satisfactory result rather than the best one when they are faced with several constraints and uncertainty [19]. On the other hand, in terms of the environment, strategic and financial management are based on a stable market environment or a predictable future. In contrast, Sarasvathy [5] proposes three hypothetical foundations of effectuation, including Knightian uncertainty, goal ambiguity, and environmental isotropy.

In addition, through observing and studying the entrepreneurial expertise of entrepreneurial experts, Sarasvathy points out that effectuation differs from causation. In uncertain and unpredictable environments, entrepreneurs who adopt an effectual framework try to identify multiple potential markets. In this process, they usually take advantage of existing means and contingencies to create possible outcomes. Predictable information is ignored, and investment loss must be affordable. Furthermore, they tend to integrate more scarce resources by creating a community of interest in their interactions with external resource holders [6].

Later, Sarasvathy and Venkataraman [20] added environmental changes to the previous dynamic model of effectuation to develop the final dynamic model of effectuation (see Figure 2). Entrepreneurs often begin with their own existing means, namely "who I 
am, what I know, whom I know". Then, they determine what they can do and the possible effects based on a set of given means. At the same time, they actively interact with people they know, so as to obtain stakeholder commitments and generate new means or new goals.

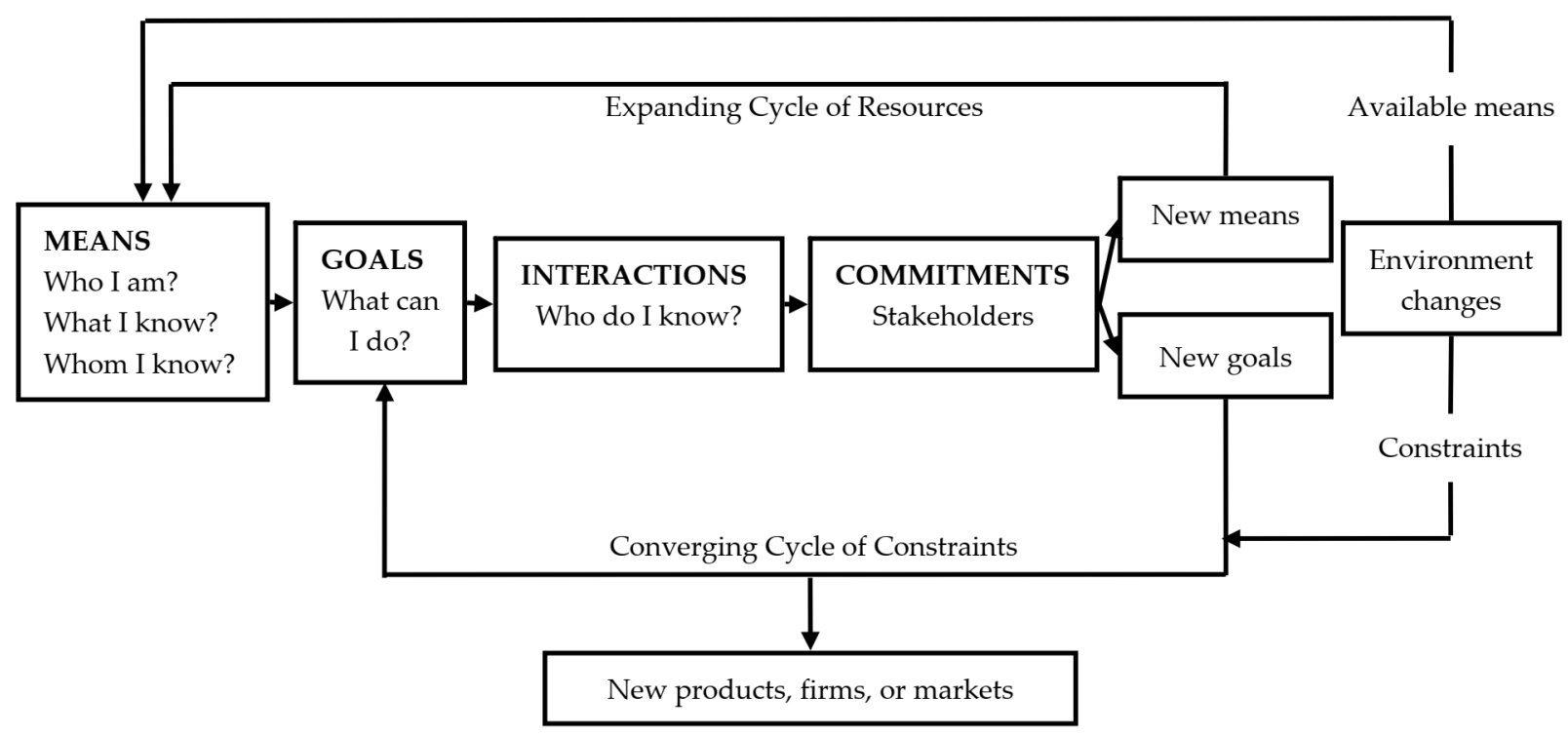

Figure 2. The dynamic model of effectuation.

These new means and goals generate two cycles, namely an expanding cycle of resources and a converging cycle of constraints. An expanding cycle of resources means that entrepreneurs can repeat the above process through new means and new resources. Then, they establish strategic alliance with more stakeholders to obtain more means and resources. A converging cycle of constraints is one in which goals of new ventures become clearer as constraints increase. Then, new products, new firms, and new markets are finally formed. In addition, environmental changes are constantly acting on the entire effectual decision-making process by influencing existing means, new means, and new goals.

Sarasvathy [6] has provided a detailed comparison and elaboration of causation and effectuation. However, there are few operational studies on the two logics. Therefore, some scholars have begun to explore their measurement. Chandler et al. [21] find that causation is a unidimensional concept, and its measurement items have good internal consistency. However, their research on the measurement dimensions of effectuation has not yielded clear conclusions. Chandler et al. [22] conducted factor analysis using two sets of enterprise data collected at different periods, and they propose that effectuation is composed of four dimensions: experimentation, affordable loss, flexibility, and pre-commitments. This study makes up for the deficiencies of previous studies. Read et al. [12] obtained an accurate measurement scale for effectuation. They present a meta-analysis of the effectual principles of means, partnerships, affordable loss, and leveraging contingencies. Mauer et al. [13] and Roach et al. [15] obtained the same four dimensions as Read et al.

Meanwhile, Brettel et al. [7] conducted research on 123 R\&D projects. Their results yielded dimensions of effectuation including means orientation, partnerships, affordable loss, and leveraging contingencies. The dimensions of causation included goal orientation, expected returns, competitive analysis, and avoiding contingencies. This work by Brettel et al. pioneers a bidirectional decision continuum scale of causation and effectuation that has been widely recognized in academia; scholars have used this scale to conduct empirical studies and obtain significant research results.

\subsection{The Effects of Entrepreneurial Decision-Making Logic on Entrepreneurial Performance}

Early research on entrepreneurial decision-making logic mainly discusses the differences and dimensions of effectuation and causation. With further in-depth study of 
entrepreneurial decision-making logic, scholars have shifted their focus to its impact on entrepreneurial performance. Case studies and empirical research have been conducted to explore the relationship between entrepreneurial decision-making logic and entrepreneurial performance, with two main views developing as follows.

The first fully recognizes the influence of effectuation in driving new venture performance but questions the role of causation. In their meta-analysis, Read et al. [12] verify that means, partnerships, and leveraging contingencies all play a significant positive role in entrepreneurial performance, but affordable loss is not related to it. Forster and York [23] analyze survey data from PSED (Panel Study of Entrepreneurial Dynamics), and suggest that the four dimensions of effectuation all have a significant effect on new venture performance, but causation is negatively correlated with it. Garonne et al. [14] argue that new ventures following effectuation can achieve better performance than those following causation under conditions of high uncertainty. McKelvie and Chandler [24] prove that affordable loss, flexibility, and pre-commitments have a positive impact on short-term financial performance, and Heydenrych and Urban [25] believe that experimentation, flexibility, and pre-commitments can promote new venture performance. Cai et al. [26] also indicate that effectuation has a positive effect on new venture performance. Finally, Szambelan [27] finds that leveraging contingencies and means orientation can promote innovation performance.

Some other scholars suggest that both effectuation and causation can promote new venture performance. Kraaijenbrink et al. [28] believe that causation and effectuation can coexist, and combining them can promote the development of new ventures. Smolka et al. [16] indicate that not only does the separate use of causation and effectuation have a positive impact on new venture performance, but their coordinated use can also contribute. Guo et al. [29] take Chinese internet ventures as their research objects, and find that both effectuation and causation positively affect new internet venture growth through the mediating role of resource bundling. Laskovai et al. [30] analyze data from 3411 student entrepreneurs from 24 countries, and show that causation and effectuation both significantly promote new venture performance. Welter et al. [31] suggest that the use of causation can significantly improve entrepreneurial performance in situations characterized by uncertainty and risk with a predictability greater than $75 \%$. Futterer et al. [32] point out that both effectuation and causation positively affect entrepreneurial performance in the context of moderate industry growth. Finally, Vanderstraeten et al. [33] prove that combining causation and effectuation positively relates to innovativeness, especially in stable environments.

\subsection{New Venture Sustainability}

Since the 1980s, due to the unfettered use of natural resources, the ecological balance has been disrupted, and environmental problems are becoming increasingly serious. The International Union for the Conservation of Nature has issued an appeal to the world: "The fundamental relationships among nature, society, ecology, economy and the use of natural resources must be studied to ensure global sustainability." In 1987, the World Commission on Environment and Development officially proposed the concept of "sustainability" in a report entitled "Our Common Future". Sustainability has since been defined as "meeting the needs of the present without compromising the ability of future generations to meet their needs", and it has gradually spread from the initial environmental field to various fields. Among these, new venture sustainability, as the basis of social and economic sustainability, has been shown to play a decisive role in the long-term development of new ventures. Therefore, it has been widely investigated by academia.

Currently, scholars have not reached a unanimous conclusion about the concept of new venture sustainability. Brown et al. [34] argue that new venture sustainability mainly consists of equity, sustainability, and commonality, and it is an ecological concept with economic implications. Beaumont [35] thinks that new ventures should integrate social responsibility, environmental protection, and economic growth into both their business 
planning and their decision-making processes in order to achieve sustainability. According to Eric, new venture sustainability means that in the processes of production, operation, and profit making, new ventures should consider short-term profit targets, market share, and long-term sustainable profitability at the same time. Ronald et al. [36] believe that new venture sustainability refers to the pursuit and efforts of a new venture in balancing social, economic, and environmental goals, while Salzmann [37] emphasizes that new ventures need to consider many factors such as the environment, society, and profit to realize sustainability.

Achieving sustainability is a goal of every new venture. However, it is not clear what factors affect new venture sustainability. Lots of scholars have explored this question, initially focusing on the influence of the internal characteristics of a venture on its sustainability from a micro-perspective. Zhang et al. [38] conduct a survey with a sample of 146 new US ventures, and find that capabilities are essential for new venture sustainability under different levels of competitive intensity. Capabilities are mainly manifested in marketing, technology, market-linking, and information technology. Rahman et al. [39] suggest that new ventures should identify initial resilience-type barriers to deal with some of the identified adversities in international entrepreneurship. It can develop their knowledge-generation potential and enhance their resilience-generation properties, which is conducive to new venture sustainability. Ortrud et al. [40] prove that asset size, capital structure, R\&D investment intensity, and the number of potential competitors all affect new venture sustainability, while Banker et al. [41] affirm the role of differentiation strategy in promoting new venture sustainability.

More recently, scholars have begun to analyze the factors that influence new venture sustainability from a more diversified perspective, especially in terms of environment and social responsibility. Teng et al. [42] indicate that the market development environment and ecological values have a notable impact on new venture sustainability. Furthermore, economic value and social participation are critical paths to achieve sustainable development goals. Igwe et al. [43] note that the entrepreneurial ecosystem and institutional environment influence frugal innovation and informal entrepreneurship. In a healthy functioning entrepreneurial ecosystem, various forms of economic and social environment contribute to new venture sustainability. For Ma et al. [44], entrepreneurial ethics have a positive impact on entrepreneurial performance, which is conducive to the sustainable growth of new ventures. Asif et al. [45] and Suganthi [46] believe that actively assuming social responsibility plays a role in promoting new venture sustainability, and Nurunnabi et al. [47] emphasize that the undertaking of social responsibility contributes to new venture sustainability by improving energy efficiency.

The above influencing factors, such as the implementation of a differentiation strategy, the intensity of R\&D investment, and whether to undertake social responsibility, all depend on entrepreneurs' decisions. The effectiveness of entrepreneurial decisions directly affects new venture sustainability [3]. However, this literature review has also found that few scholars have directly explored the relationship between them. Therefore, we aim to examine the influence of entrepreneurial decision-making logic on new venture sustainability. The study will enrich the current body of research on entrepreneurial outcomes related to entrepreneurial decision-making logic. In addition, taking a micro-perspective to study entrepreneurial behavior may provide some indications for future explorations of the inherent laws of new venture sustainability.

\section{Hypothesis}

Based on entrepreneurial decision-making theory, this study focuses on the following question: "how do different entrepreneurial decision-making logics affect new venture sustainability?" Causation and effectuation are seen as the two most common entrepreneurial decision-making logics $[6,14,21]$. In terms of dimensional division, this paper refers to the research of Brettel et al. [7], which has been quite influential in the academic community. Four bidirectional dimensions are selected to define causation and effectuation: 
goal orientation and means orientation; expected returns and affordable loss; competitive analysis and partnerships; and avoiding contingencies and leveraging contingencies. These reflect entrepreneurs' attitudes towards action, benefits, costs, stakeholders, and contingencies. It should be noted that these four bidirectional dimensions are not completely opposite, and the same entrepreneur may make use of two different entrepreneurial decision-making logics.

\subsection{Causation and New Venture Sustainability}

\subsubsection{Goal Orientation and New Venture Sustainability}

The entrepreneurial process of causation begins with new ventures' given goals, and takes these goals as the guide for entrepreneurial action. However, new ventures' activities are also limited by their goals, meaning that new ventures may not find it easy to react when new opportunities arise and additional possibilities offered by other available means can easily be ignored, which may prevent new ventures from seizing opportunities and making innovations. In addition, goal-driven decision making emphasizes the integration of resources and the selection of optimal solutions to achieve the given goals [31]. This makes new ventures integrate resources to the maximum extent, rather than making use of existing resources effectively. In this process, the effective utilization of resources is restricted and the cost of entrepreneurship increases, both of which affect new venture sustainability. Therefore, Hypothesis 1a is proposed:

Hypothesis 1a (H1a). Goal orientation has a negative effect on new venture sustainability.

\subsubsection{Expected Returns and New Venture Sustainability}

New ventures following causation focus on the calculation of expected returns and expect to maximize returns [5]. However, to estimate expected returns, new ventures need to assess the market, their finances, and future sales. In the entrepreneurial process, acquiring this information costs time and money. This distracts new ventures, so opportunities may slip away while entrepreneurs search for information [48]. In addition, new ventures must bear the corresponding risks when pursuing the maximization of expected returns. New ventures following causation do not pay attention to the assessment of affordable loss, but if the business fails, it may bring incalculable loss, and even lead to bankruptcy. Therefore, we propose Hypothesis $1 \mathrm{~b}$ :

Hypothesis $\mathbf{1 b}(\mathbf{H 1 b})$. Expected returns have a negative effect on new venture sustainability.

\subsubsection{Competitive Analysis and New Venture Sustainability}

In the theory of causation, specifically the classical Porter competition model [49], competition strategy is placed at the core. However, this is more suitable for stable and structured industrial markets. In the entrepreneurial process, new ventures are not faced with a competitive "Red Sea Market" in the traditional concept, but with a potential "Blue Sea Market". Competitive strategy and competitive advantage are no longer key to the success of entrepreneurship [50], but innovation is critical. It is also hard for new ventures to conduct accurate and effective competitive analysis due to high environmental uncertainty and lack of resources. If they excessively emphasize competition, this may be equivalent to devoting limited resources into invalid competitive analysis, which is not conducive to new venture sustainability. Therefore, we propose Hypothesis 1c:

Hypothesis 1c (H1c). Competitive analysis has a negative effect on new venture sustainability.

\subsubsection{Avoiding Contingencies and New Venture Sustainability}

New ventures following causation always avoid contingencies and try to achieve their goals through planning [5]. On the one hand, contingencies may contain new entrepreneurial opportunities, and can promote the innovation of business models and 
organizational structure. Avoiding contingencies causes new ventures to miss opportunities that may be conducive to new venture sustainability. On the other hand, in the early stages of entrepreneurship, environmental changes are dramatic and accidents are prone to occur-not all can be avoided. An accident that is not conducive to new venture sustainability may be a blow to a new venture, and lead to actions to try to avoid it. This breaks the original plan, disrupts entrepreneurial activities, and may even lead to failure. Hence, Hypothesis $1 \mathrm{~d}$ is proposed:

Hypothesis 1d (H1d). Avoiding contingencies has a negative effect on new venture sustainability.

\subsection{Effectuation and New Venture Sustainability}

\subsubsection{Means Orientation and New Venture Sustainability}

Unlike causation, the entrepreneurial process of effectuation begins with available means [5]. When starting a business, consideration is given to the existing means and resources. This avoids an increase in entrepreneurial costs brought by the integration of resources from the outside, and improves the utilization efficiency of entrepreneurial resources. In addition, a full analysis of existing means and entrepreneurial resources can help new ventures to identify opportunities that are suitable for them [1], so as to achieve a match between new ventures and entrepreneurial opportunities. These discussions lead to Hypothesis 2a:

Hypothesis 2a (H2a). Means orientation has a positive effect on new venture sustainability.

\subsubsection{Affordable Loss and New Venture Sustainability}

New ventures following effectuation focus on estimating affordable loss [5]. In the entrepreneurial process, the setting of affordable loss reduces new ventures' reliance on predicting. New ventures only need to assess the worst results that they can bear before starting a business, and set a ceiling on affordable loss. Then, the focus of decision making can be within the entrepreneur's control on this basis. If a project's risk level does not reach the threshold of affordable loss, the entrepreneur does not give it up easily. This improves decision-making efficiency, brings a certain psychological security to the entrepreneur, and reduces the impact of uncertainty at the beginning of the venture, thus contributing to new venture sustainability. Therefore, this paper proposes Hypothesis $2 \mathrm{~b}$ :

Hypothesis $\mathbf{2 b}(\mathbf{H} \mathbf{2} \mathbf{b})$. Affordable loss has a positive effect on new venture sustainability.

\subsubsection{Partnerships and New Venture Sustainability}

Both entrepreneurs and new ventures need to build many relationships. Only those that take risks and share gains together can be described as partnerships in effectuation [12]. Based on risk sharing, the uncertainty of the initial stage of entrepreneurship decreases. As new ventures build alliances with customers, suppliers, and even potential competitors, their means and resources increase. Entrepreneurs can actively integrate their new resources with existing resources to create new combinations. This eases the scarcity of resources to a certain extent in the initial stage of entrepreneurship, enhances new ventures' competitiveness, and promotes the identification of new opportunities [12]. Therefore, we propose Hypothesis 2c:

\section{Hypothesis 2c (H2c). Partnerships have a positive effect on new venture sustainability.}

\subsubsection{Leveraging Contingencies and New Venture Sustainability}

New ventures following effectuation advocate accepting and leveraging contingencies. Contingencies are inevitable in the entrepreneurial process, and how new ventures deal with them has a significant impact on entrepreneurial performance [7,12]. Effectuators consider them as opportunities to make money [5]. Compared with novice entrepreneurs, en- 
trepreneurial experts always maintain organizational flexibility during the entrepreneurial process. They can continuously adapt to changes in the external environment, they are ready for contingencies with a positive attitude, and they usually regard contingencies as available resources and proactively turn them into entrepreneurial opportunities [9]. In GUESSS (Global University Enterprise Spiritual Students' Survey), Smolka and Verheul [16] recruited a sample of 1453 undergraduate entrepreneurs from 25 countries, and found that maintaining the flexibility of new ventures has a positive effect on entrepreneurial performance. Roach et al. [15] focus on entrepreneurs running small- and medium-sized enterprises in the US electronics manufacturing industry, and find that leveraging contingencies is conducive to improving the innovation ability of new ventures and achieving firm sustainability. Therefore, we propose Hypothesis $2 \mathrm{~d}$ :

Hypothesis 2d (H2d). Leveraging contingencies has a positive effect on new venture sustainability.

\section{Methods}

\subsection{Sample and Procedures}

This study is based on datasets from CPSED, which is implemented by the Research Center of Entrepreneurship at Nankai University. To a certain extent, the CPSED overcomes the hindsight bias and survivor bias that may exist in convenience sampled cross-sectional data. The CPSED is the first entrepreneurial dynamic survey project in China, focusing on the inherent laws of entrepreneurial activities from a micro-perspective and using the stratified sampling method. In the context of intensive entrepreneurial activity, China is divided into four major regions, namely the east region, the west region, the northeast region, and the central region. Considering differences in the prevalence of entrepreneurial activity among these regions, the CPSED selects Beijing, Tianjin, Hangzhou, and Guangzhou to represent the eastern region. Chengdu and Xi'an represent the western region, Wuhan represents the central region, and Shenyang represents the northeast region. In each surveyed city, the CPSED investigates adults over 18-years-old. The weighting of the survey sample distribution in each city is determined by the population of the city.

The CPSED allocates a sample size to each surveyed city. In order to ensure the representativeness of the telephone sampling used in the original survey, we collected data on the telephone penetration rate in the surveyed cities. The results of our analysis indicate that the telephone penetration rate in the surveyed cities was relatively high (Beijing $90 \%$, Chengdu 93\%, Guangzhou 96\%, Hangzhou 95\%, Shenyang 76\%, Tianjin 91.6\%, Wuhan $89 \%$, and $\mathrm{Xi}^{\prime}$ an $81 \%$ ). Thus, we are able to conclude that telephone sampling yielded a relatively comprehensive sample coverage rate.

The main standards used by the CPSED to screen nascent entrepreneurs include: (a) have acted to start a new venture, (b) have ownership of a new venture, (c) have been in the process of new venture emergence, and (d) have not earned sales revenue (as shown in Figure 3).

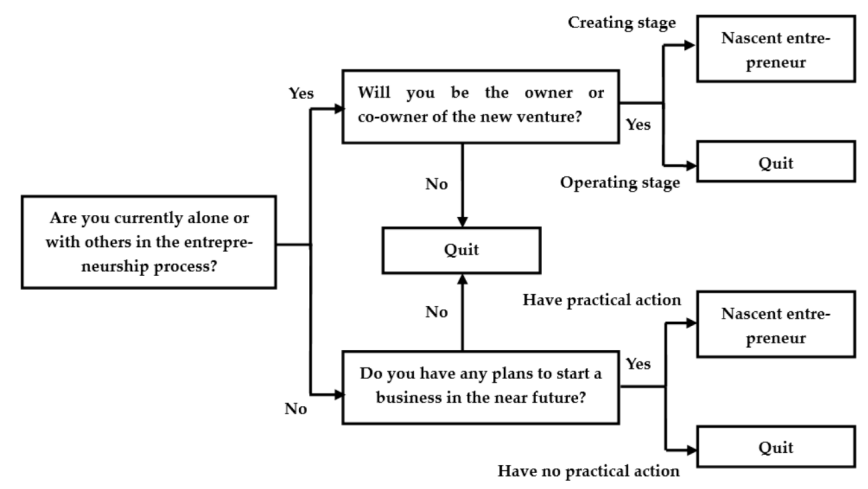

Figure 3. Screening criteria for new entrepreneurs (CPSED). 
The CPSED project team conducted a three-wave pilot study. In the first stage of the formal investigation, the project team interviewed 22,045 people by telephone after contacting 69,990 Chinese households. Among those contacted, 974 nascent entrepreneurs were identified, 601 of whom completed the first wave of telephone interviews. A year later, a second wave of telephone tracking surveys was conducted with these entrepreneurs. Three hundred twenty-one nascent entrepreneurs took part in these interviews. Among this group, 29 nascent entrepreneurs had entered the state of business operation, 175 were still in the state of entrepreneurial preparation, while 117 had ceased entrepreneurial activities.

We conducted a preliminary analysis of the data from the 321 nascent entrepreneurs who were identified in the first two rounds of the CPSED. "Registered as a legal entity" signifies that the new venture exists as an organization, rather than as an entrepreneurial idea. This is a milestone in the commercialization of entrepreneurial opportunities, and determines the direction of new venture sustainability [51]; that is, it is possible to achieve sustainability only after a new venture is registered as a legal entity. Considering that this study aims to explore the effects of entrepreneurial decision-making logic on new venture sustainability, we removed the data for the registered individuals in the first round. Finally, 259 valid participants remained. Descriptive statistics for the sample characteristics are given in Table 1.

Table 1. Characteristics of sampling distribution $(\mathrm{N}=259)$.

\begin{tabular}{|c|c|c|c|c|c|c|c|}
\hline Index & Attribute & Sample & Percentage $(\%)$ & Index & Attribute & Sample & Percentage (\%) \\
\hline \multirow{2}{*}{ Gender } & female & 85 & 32.8 & \multirow{2}{*}{$\begin{array}{l}\text { Previous entrepreneurial } \\
\text { experience }\end{array}$} & yes & 67 & 25.9 \\
\hline & male & 174 & 67.2 & & no & 192 & 74.1 \\
\hline \multirow{4}{*}{ Age } & $17-30$ & 164 & 63.3 & \multirow{2}{*}{ Previous work experience } & yes & 208 & 80.3 \\
\hline & $31-50$ & 68 & 26.3 & & no & 51 & 19.7 \\
\hline & 50 or over & 21 & 8.1 & \multirow{2}{*}{ Team entrepreneurship } & yes & 128 & 49.4 \\
\hline & unknown & 6 & 2.3 & & no & 131 & 50.6 \\
\hline \multirow{5}{*}{ Education } & junior high or below & 25 & 9.7 & \multirow{2}{*}{$\begin{array}{c}\text { Technology } \\
\text {-oriented enterprises }\end{array}$} & yes & 92 & 35.5 \\
\hline & senior high & 64 & 24.7 & & no & 167 & 64.5 \\
\hline & junior college & 74 & 28.6 & \multirow{3}{*}{$\begin{array}{l}\text { Entrepreneurship } \\
\text { education/training }\end{array}$} & yes & 86 & 33.2 \\
\hline & Bachelor & 90 & 34.7 & & & & \\
\hline & Master's or above & 6 & 2.3 & & no & 173 & 66.8 \\
\hline
\end{tabular}

\subsection{Measures}

\subsubsection{Independent Variables}

The independent variables in this study are causation and effectuation. Specifically, causation includes goal orientation, expected returns, competitive analysis, and avoiding contingencies. Effectuation includes means orientation, partnerships, affordable loss, and leveraging contingencies.

\section{(1) Causation}

Goal orientation: New ventures following causation tend to be goal-driven. They develop clear business plans beforehand and then implement entrepreneurial activities according to their plans, so as to achieve the goals. Therefore, we chose the question "Did you prepare a business plan when you started your business?" to indicate goal orientation.

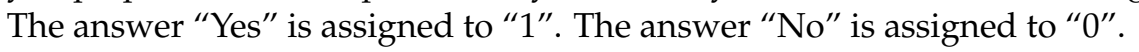

Expected returns: New ventures following causation give priority to the returns of entrepreneurial activity rather than to the costs of inputs and affordable loss. Therefore, we chose the question "There are three factors, which are company income, personal income, and investment cost, in the process of entrepreneurship. Which one should be considered most in your mind?" to indicate expected returns. The answers "Company income" and "Personal income" are assigned to " 1 ". The answer "Investment cost" is assigned to " 0 ".

Competitive analysis: New ventures following causation particularly care about competition. They usually conduct adequate market research and competitive analyses [10]. Therefore, we chose the question "Do you collect information about customers, markets, 
and competitors?" to indicate competitive analysis. The answer "Yes" is assigned to " 1 ". The answer "No" is assigned to " 0 ".

Avoiding contingencies: Based on the extensive analysis and prediction of potential risks, new ventures following causation try their best to avoid contingencies. Therefore, we chose the question "Do you analyze and forecast investment risks?" to indicate avoiding contingencies. The answer "Yes" is assigned to " 1 ". The answer "No" is assigned to " 0 ".

\section{(2) Effectuation}

Means orientation: Means orientation indicates that new ventures tend to use their existing means and resources, rather than looking for additional means based on their goals. In the entrepreneurial process, new ventures following effectuation have no clear goals. Their market is not yet clear. The mining of business opportunities mostly depends on existing resources and advantages. Therefore, we chose the question "What is the main reason why you think something is a business opportunity?" to indicate means orientation. The answers "It can take advantage of the resources you have" and "It can develop your strengths and advantages" are assigned to " 1 ". The answers "It solves a problem or fills an unmet demand" and "It has led to a similar business success" are assigned to " 0 ".

Affordable loss: New ventures following effectuation always evaluate the loss caused by risks. Once the risk exceeds their ability to bear the associated loss, new ventures choose to give up on the opportunity. Therefore, we chose the question "If you find that the risk exceeds your expectations or the cost of investment exceeds your ability to bear, do you give up on starting a business?" to indicate affordable loss. The answer "Yes" is assigned to " 1 ". The answer "No" is assigned to " 0 ".

Partnerships: New ventures following effectuation are more inclined to reach a precommitment with friends, customers, suppliers, investors, and financing institutions. Then, they share entrepreneurial risks with these stakeholders [22]. Therefore, we chose the question "Did you start your business alone or in partnership with others?" and "Did you raise money from other people or institutions?" to indicate partnerships. The answers "Partnership" and "Yes" are assigned to " 1 ". The answers "Alone" and "No" are assigned to " 0 ".

Leveraging contingencies: New ventures following effectuation tend to leverage contingencies. They do not spend lots of time and effort in predicting risks. Leveraging contingencies and avoiding contingencies are the opposite of decision-making logic. In essence, they reflect entirely different preferences for risks. Therefore, we chose the question "Do you analyze and forecast investment risks?" to indicate leveraging contingencies. The answer " $\mathrm{No}^{\prime}$ is assigned to " 1 ". The answer "Yes" is assigned to " 0 ".

\subsubsection{Dependent Variables}

Legitimation plays an important role in new venture sustainability. It is an institutionally embedded process for new ventures to overcome legitimacy thresholds and obtain resources [52]. For new ventures adopting a legitimation strategy, only those that can cross the legitimacy threshold are likely to achieve sustainability; otherwise, they face a significant risk of failure [53]. After registration, new ventures begin to create economic profits and assume corporate social responsibility in the form of legal entities. They accept the supervision of environmental regulatory authorities and make efforts towards environmental protection. Registration is a milestone in new venture sustainability. From the perspective of legitimacy, this paper selects the indicator that the new venture has become a legal entity to measure new venture sustainability. Therefore, we chose the question "Have you registered with the Commerce and Industry Department?" to indicate new venture sustainability. The answer "Yes" in the second round of interviews is assigned to " 1 ". The answer "No" is assigned to " 0 ".

\subsubsection{Control Variables}

Based on previous research, this paper chose five control variables. They are the entrepreneur's gender, age, education, previous entrepreneurial experience, and previous 
work experience. Gender, previous entrepreneurial experience, and previous work experience are dummy variables, where "Male" and "Yes" are assigned to " 1 ", and "Female" and "No" are assigned to " 0 ". Age is a continuous variable. Education is a multi-categorical variable divided into junior high or below, senior high, junior college, Bachelor, and Master's or above. " 1 " denotes junior high or below, "2" denotes senior high, " 3 " denotes junior college, " 4 " denotes Bachelor, and " 5 " denotes Master's or above.

\subsection{Statistical Methods}

Since the dependent variable "new venture sustainability" is dichotomous, we adopted a binominal logistic regression analysis to examine the effects on new venture sustainability in terms of the four dimensions of causation and effectuation, respectively. This paper utilized hierarchical logistic regression analysis.

\section{Results}

\subsection{Descriptive Statistics for the Variables}

A descriptive statistical analysis was performed for each variable; Table 2 shows the results. Sixty-seven percent of the entrepreneurs were male. The average age of the entrepreneurs was about 31-years-old. The average education level of the entrepreneurs was 2.95. Twenty-six percent of the entrepreneurs had previous entrepreneurial experience, and $80 \%$ had previous work experience.

Table 2. Descriptive statistics for the variables.

\begin{tabular}{cccccc}
\hline No. & Variables & Min & Max & Mean & Standard Deviation \\
\hline 1 & Gender & 0.00 & 1.00 & 0.67 & 0.47 \\
2 & Age & 17.00 & 70.00 & 31.40 & 10.66 \\
3 & Education & 1.00 & 5.00 & 2.95 & 1.04 \\
4 & Previous entrepreneurial experience & 0.00 & 1.00 & 0.26 & 0.44 \\
5 & Previous work experience & 0.00 & 1.00 & 0.80 & 0.40 \\
6 & Goal orientation & 0.00 & 1.00 & 0.62 & 0.49 \\
7 & Expected returns & 0.00 & 1.00 & 0.50 & 0.50 \\
8 & Competitive analysis & 0.00 & 1.00 & 0.69 & 0.46 \\
9 & Avoiding contingencies & 0.00 & 1.00 & 0.70 & 0.46 \\
10 & Means orientation & 0.00 & 1.00 & 0.51 & 0.50 \\
11 & Affordable loss & 0.00 & 1.00 & 0.36 & 0.48 \\
12 & Partnerships & 0.00 & 1.00 & 0.54 & 0.50 \\
13 & Leveraging contingencies & 0.00 & 1.00 & 0.30 & 0.46 \\
& New venture sustainability & 0.00 & 1.00 & 0.20 & 0.40 \\
\hline
\end{tabular}

\subsection{Correlation Analysis}

The correlation coefficient matrix for the variables is shown in Table 3. The entrepreneur's gender $(\gamma=0.144, p<0.1)$ and previous work experience $(\gamma=0.185, p<0.05)$ both showed a significant positive correlation with new venture sustainability. The entrepreneur's age $(\gamma=0.002, p>0.1)$, education $(\gamma=-0.013, p>0.1)$, and previous entrepreneurial experience $(\gamma=-0.069, p>0$. 1) did not significantly correlate with new venture sustainability. Leveraging contingencies has a significant negative correlation with new venture sustainability $(\gamma=-0.210, p<0.01)$. The correlation coefficients among the variables are relatively small, and there is no multi-collinearity among them. Thus, regression analysis can be performed. 
Table 3. Correlation coefficient matrix for all variables.

\begin{tabular}{|c|c|c|c|c|c|c|c|c|c|c|c|c|c|c|c|}
\hline & Variables & 1 & 2 & 3 & 4 & 5 & 6 & 7 & 8 & 9 & 10 & 11 & 12 & 13 & 14 \\
\hline 1 & Gender & 1 & & & & & & & & & & & & & \\
\hline 2 & Age & 0.065 & 1 & & & & & & & & & & & & \\
\hline 3 & Education & -0.039 & $-0.120 *$ & 1 & & & & & & & & & & & \\
\hline 4 & $\begin{array}{l}\text { Previous entrepreneurial } \\
\text { experience }\end{array}$ & 0.075 & $0.159^{* *}$ & $-0.110^{*}$ & 1 & & & & & & & & & & \\
\hline 5 & Previous work experience & 0.067 & 0.039 & $0.137^{* *}$ & -0.040 & 1 & & & & & & & & & \\
\hline 6 & Goal orientation & $0.133^{* *}$ & -0.065 & $0.111 *$ & 0.006 & 0.094 & 1 & & & & & & & & \\
\hline 7 & Expected returns & 0.071 & 0.001 & -0.097 & 0.029 & -0.031 & 0.061 & 1 & & & & & & & \\
\hline 8 & Competitive analysis & 0.102 & -0.104 * & $0.123 * *$ & -0.063 & $0.131 * *$ & $0.271^{* * *}$ & -0.048 & 1 & & & & & & \\
\hline 9 & Avoiding contingencies & $0.151^{* *}$ & -0.033 & $0.247^{* * *}$ & 0.023 & $0.204^{* * *}$ & $0.251^{* * *}$ & -0.003 & $0.235^{* * *}$ & 1 & & & & & \\
\hline 10 & Means orientation & 0.049 & 0.028 & -0.029 & -0.051 & 0.054 & -0.007 & 0.073 & 0.058 & 0.024 & 1 & & & & \\
\hline 11 & Affordable loss & -0.031 & $0.173^{* * *}$ & -0.014 & 0.041 & $0.104 *$ & 0.013 & 0.100 & $-0.115 *$ & -0.005 & -0.025 & 1 & & & \\
\hline 12 & Partnerships & 0.043 & -0.070 & $0.213^{* * *}$ & $0.141 * *$ & 0.027 & 0.121 & $-0.158^{* *}$ & $0.133 * *$ & 0.099 & 0.057 & -0.006 & 1 & & \\
\hline 13 & Leveraging contingencies & $-0.151^{* *}$ & 0.033 & $0.213^{* * *}$ & -0.023 & $-0.204^{* * *}$ & $-0.251^{* * *}$ & 0.003 & $-0.235 * * *$ & $-1.000 * * *$ & -0.024 & 0.005 & -0.099 & 1 & \\
\hline 14 & New venture sustainability & 0.144 * & 0.002 & -0.013 & -0.069 & $0.185^{* *}$ & -0.069 & -0.049 & 0.010 & $0.210 * * *$ & -0.095 & -0.037 & 0.103 & $-0.210 * * *$ & 1 \\
\hline
\end{tabular}

Notes: ${ }^{*} p<0.1,{ }^{* *} p<0.05,{ }^{* * *} p<0.01$ 


\subsection{Hypothesis Testing}

Table 4 shows the logistic regression results for entrepreneurial decision-making logic and new venture sustainability. The Chi-square $\left(\chi^{2}\right)$ likelihood ratios of models 1 to 3 are $10.761(p<0.1), 21.022(p<0.05)$, and $24.779(p<0.01)$, respectively. All three models are significant overall. Compared with model 1, the values of Cox and Snell $R^{2}$ and Nagelkerke $\mathrm{R}^{2}$ for models 2 and 3 are both greater. This indicates that the addition of new variables improves the interpretation of the dependent variables, and the degree of model fit is good.

Table 4. Hierarchical linear regression for new venture sustainability.

\begin{tabular}{|c|c|c|c|}
\hline \multirow{2}{*}{ Variables } & Model 1 & Model 2 & Model 3 \\
\hline & Coefficient & Coefficient & Coefficient \\
\hline Constant & -3.470 & -3.641 & -2.564 \\
\hline Gender & 0.869 & 0.909 & 0.998 \\
\hline Age & 0.000 & -0.003 & 0.006 \\
\hline Education & -0.112 & -0.224 & $-0.386 *$ \\
\hline Previous entrepreneurial experience & -0.415 & -0.498 & -0.638 \\
\hline Previous work experience & $1.989 *$ & $1.987 *$ & $2.219 * *$ \\
\hline Goal orientation & & $-0.851 *$ & \\
\hline Expected returns & & -0.251 & \\
\hline Competitive analysis & & -0.141 & \\
\hline Avoiding contingencies & & $1.725^{* *}$ & \\
\hline Means orientation & & & $-1.090 * *$ \\
\hline Affordable loss & & & -0.449 \\
\hline Partnerships & & & $0.880 *$ \\
\hline Leveraging contingencies & & & $-1.827 * *$ \\
\hline Chi-Square $\chi^{2}$ & $10.761 *$ & $21.022 * *$ & $24.779 * * *$ \\
\hline-2 Log Likelihood & 139.360 & 129.099 & 125.342 \\
\hline Cox and Snell $\mathrm{R}^{2}$ & 0.069 & 0.131 & 0.152 \\
\hline Nagelkerke R ${ }^{2}$ & 0.109 & 0.207 & 0.241 \\
\hline Df & 6 & 10 & 10 \\
\hline
\end{tabular}

Notes: ${ }^{*} p<0.1,{ }^{* *} p<0.05,{ }^{* * *} p<0.01$.

Model 1 is the regression model for the control variables. There is a significant positive correlation between previous work experience and new venture sustainability $(\beta=1.989, p<0.1)$. In other words, entrepreneurs' previous work experience contributes to new venture sustainability. However, entrepreneurs' gender, age, education, and previous entrepreneurial experience show no statistically significant correlation with new venture sustainability.

In model 2, there is a significant negative relationship between goal orientation and new venture sustainability $(\beta=-0.851, p<0.1)$. Thus, H1a is supported. The relationship between expected returns and new venture sustainability is negative $(\beta=-0.251, p>0.1)$. The effect of competitive analysis on new venture sustainability is also negative $(\beta=-0.141$, $p>0.1$. However, neither regression coefficient reaches statistically significant levels. Thus, $\mathrm{H} 1 \mathrm{~b}$ and $\mathrm{H} 1 \mathrm{c}$ are rejected. Avoiding contingencies has a positive influence on new venture sustainability $(\beta=1.725, p<0.05)$. Thus, $\mathrm{H} 1 \mathrm{~d}$ is reverse supported.

Model 3 shows that the negative relationship between means orientation and new venture sustainability is significant $(\beta=-1.090, p<0.05$ ). Thus, $\mathrm{H} 2 \mathrm{a}$ is reversely supported. The negative relationship between affordable loss and new venture sustainability is not significant $(\beta=-0.449, p>0.1$ ), which means that $\mathrm{H} 2 \mathrm{~b}$ is not supported. There is a positive relationship between partnerships and new venture sustainability $(\beta=0.880, p<0.1)$, and thus, $\mathrm{H} 2 \mathrm{c}$ is supported. Leveraging contingencies has a negative effect on new venture sustainability $(\beta=-1.827, p<0.05)$. Thus, $\mathrm{H} 2 \mathrm{~d}$ is reversely supported.

\section{Discussion and Implications}

\subsection{Discussion}

In this section, we discuss the results of this study from the following aspects. First, from the starting point of entrepreneurs' actions, both goal orientation and means orientation have a negative effect on new venture sustainability. This conclusion about goal 
orientation is consistent with the results presented by previous scholars [7,11,32]. However, this paper reaches the opposite conclusion about means orientation. The majority of scholars believe that means orientation can promote new venture performance $[13,23,27]$. Our suggested reasons for this difference are that, on the one hand, means orientation emphasizes the use of existing resources, so it may inhibit the development of promising innovative opportunities and reduce the utilization efficiency of strategic resources. Especially for novice entrepreneurs, it can be very difficult to determine how to use existing resources [9]. On the other hand, in entrepreneurial practice, entrepreneurs adopt both causation and effectuation $[28,54,55]$. In the early stages of entrepreneurship when there is high uncertainty, entrepreneurs may not have a clear direction. Not only do they rely on existing means as a starting point for action, but they may also rely on given goals as a direction to explore. A single entrepreneurial decision-making logic may be a constraint that limits the possibilities available to entrepreneurs, but a synergistic use of goal-driven and means-driven logic may be more applicable to entrepreneurial decisions [16]. Therefore, goal-driven and means-driven decision making are not conducive to new venture sustainability.

Second, from the entrepreneurs' analysis of benefits and costs, affordable loss and expected returns do not significantly affect new venture sustainability. This conclusion is similar to the research of most scholars- that is, affordable loss and expected returns have no significant effect on new venture performance $[11,24,28]$. This paper provides support for their arguments. However, some scholars hold different views. Smolka et al. [16] believe that affordable loss has a negative effect on firm performance, while Forster and York [23] and Brettel [7] indicate that affordable loss can promote new venture performance. This is because the relationship between the two different decision-making logics and new venture sustainability is not simple or direct, and different moderating variables can also produce different results. Therefore, the effects of entrepreneurial decision-making logic on benefits and costs need to be further explored in different contexts.

Third, in terms of the entrepreneurs' attitudes towards stakeholders, partnerships have a positive effect on new venture sustainability, while the effect of competitive analysis on new venture sustainability is not significant. This is consistent with the results of most previous studies. In the early stages of entrepreneurship, partnerships can help new ventures obtain relevant resources and commitment from stakeholders, thereby saving entrepreneurial costs and improving entrepreneurial performance $[7,13,56]$. From this perspective, competitive analysis is not essential for entrepreneurial success [50]. Our results suggest that in the Chinese context, new ventures value cooperation more than competition, which is more conducive to new venture sustainability. In the early stages, new ventures usually lack resources and face high risks, and they do not have obvious competitive advantages. A strong emphasis on competition puts new ventures at a disadvantage, and may even trigger suppression by competitors and lead to failure and bankruptcy. Partnerships characterized by resource exchange and sharing can blur existing organizational boundaries and break through resource constraints, thereby promoting new venture sustainability. Partnerships do not mean that there is no competition, but they do place more emphasis on cooperation with stakeholders when making entrepreneurial decisions.

Fourth, in terms of entrepreneurs' attitudes towards contingencies, avoiding contingencies has a significant positive effect on new venture sustainability. In contrast, leveraging contingencies is not conducive to new venture sustainability. This conclusion is not only contrary to the expected results, but is also different from the views of many scholars $[12,13,23,27]$. The reasons for this difference are as follows. On the one hand, contingencies may present potential opportunities, but they can also be fatal threats. Especially in the early stages of entrepreneurship, for new ventures who advocate leveraging contingencies, once a contingency is beyond a new venture's ability to deal with, turning contingencies into opportunities becomes much more difficult. This may cause a fatal blow to the new venture. On the other hand, Chinese people are generally conservative, influenced by traditional culture. They usually try their best to avoid risks. For instance, in 
this study, $70 \%$ of entrepreneurs chose to avoid contingencies, while only $30 \%$ aimed to leverage contingencies. Under these conservative conditions, the decision-making logic to avoid contingencies is more in line with entrepreneurs' inner thoughts, and this can improve entrepreneurs' decision-making efficiency and help them to achieve goals faster in line with their plans. It is worth noting, however, that due to the limitations of the CPSED data, this paper selected entrepreneurs' attitude towards risks as a proxy for their attitude towards leveraging/avoiding contingencies. This measurement may not reflect the actual variable, making the empirical results inconsistent with expectations.

\subsection{Theoretical Implications}

The theoretical contribution of the research includes the following aspects. First, this paper explores a new decision-making logic in the entrepreneurial context and enriches the existing theorizing around decision-making. Traditional management decision-making theory aims to analyze the rational decision making of established enterprises. Researchers emphasize causation. However, in the process of entrepreneurship, uncertainty is usually high, and decision-making goals are often unclear. This paper encourages scholars to explore a new decision-making logic, known as effectuation. This seems to fit well with the uniqueness of the entrepreneurial context.

Second, this paper contributes to clarifying the relationship between entrepreneurial decision-making logic and entrepreneurial performance. Previous research has disputed this for a long time. Some scholars hold that effectuation can promote new venture performance and causation has a negative effect $[12,23]$, but other researchers consider that effectuation has no influence on new venture growth [57]. This paper indicates that goal orientation plays a negative role in promoting new venture sustainability, while avoiding contingencies has a positive influence. Partnerships are conducive to new venture sustainability, while means orientation and leveraging contingencies have a negative effect. This paper explores the influence of effectuation on new venture sustainability from the perspective of dimensions, and contributes to examining the effect of causation and effectuation more rationally.

Third, our paper inspires scholars to investigate the outcomes of entrepreneurial decision-making logic. Previous studies have examined the effect of entrepreneurial decision-making logic, but conclusions have been inconsistent. Some scholars have examined the influence of entrepreneurial decision-making logic from the perspective of financial and growth performance $[15,16,24,55]$, but the entrepreneurial outcomes cover many elements and need to be further explored. This study comparatively analyzes the effects of causation and effectuation on new venture sustainability, enriching differentiated research on entrepreneurial decision-making logic.

\subsection{Practical Implication}

This research also has important implications for entrepreneurial practice. On the one hand, this study will help to inform entrepreneurs about how to make decisions efficiently. It encourages them to use both causation and effectuation appropriately when making entrepreneurial decisions, so as to effectively promote new venture sustainability. Specifically, in the early stages of entrepreneurship, entrepreneurs should choose partnerships and avoid contingencies to promote new venture sustainability. They should pay attention to the disadvantages brought by means orientation, goal orientation, and avoiding contingency.

On the other hand, this paper also contributes to enriching the content of entrepreneurship education. In traditional management education, there is too much emphasis on causation. Owing to dynamic changes in their environments, entrepreneurs cannot make decisions solely according to a single decision-making logic. It is imperative to explore new theories and logics for decision-making. While cultivating a focus on causation in potential entrepreneurs, educators should also pay attention to effectuation, so that trained 
entrepreneurs can use different entrepreneurial decision-making logics flexibly in different contexts. This is conducive to new venture sustainability.

\subsection{Limitations and Directions for Future Research}

The limitations of our research are summarized as follows. First, as with much research on the relationship between entrepreneurial decision-making logic and new venture sustainability, this study was unable to consider the effect of contexts. Exploring the contextual factors surrounding entrepreneurial decision-making logic and performance is very important to understand the advantages and limitations of different entrepreneurial decision-making logics [6]. This paper does not address the question of which decisionmaking logics work best for entrepreneurs in different contexts. Therefore, follow-up research could investigate the many potential moderating variables that may have an impact, such as the scarcity of entrepreneurial resources, the stage of firm life, the newness of opportunity, and the perception of gain and loss.

Second, this study only comparatively analyzes different entrepreneurial decisionmaking logics in terms of their effects on new venture sustainability. It does not explore the effects of a synergistic use of effectuation and causation; future research on new venture sustainability should take this into account.

Third, owing to the limitations of the database, this paper measures each dimension of causation and effectuation using only one proxy index. In addition, it measures new venture sustainability only from the perspective of legitimacy. This limitation in the data means that we cannot completely reflect the essence of the variables. Future studies should measure entrepreneurial decision-making logic using mature scales, such as those developed by Chandler et al. [22] or Brettel et al. [7]. New venture sustainability should be measured by mature indicators which refer to Sharu and Chandler's research, such as perceived growth in market share, sales growth, and employment growth [58,59]. In particular, researchers should develop scales that are specifically applicable to the unique Chinese context.

Finally, new venture sustainability is a process, sometimes lasting for decades [60]. This study has only a small timespan, tracking the entrepreneurial behavior of nascent entrepreneurs over the course of a year. This may not be long enough to ensure the sustainability of new ventures; future research needs to lengthen the duration of the survey data collection period [3].

\section{Conclusions}

From the point of view of different dimensions of entrepreneurial decision-making logic, this paper investigates how causation and effectuation influence new venture sustainability. Based on an empirical analysis of large random-sampling datasets provided by CPSED, the research results indicate that both causation and effectuation affect new venture sustainability. To be specific, avoiding contingencies and seeking partnerships have a positive impact on new venture sustainability, while goal orientation, means orientation, and leveraging contingencies play a negative role. In addition, competitive analysis, affordable loss, and expected returns do not significantly affect new venture sustainability.

Author Contributions: Conceptualization, H.W. and P.W.; formal analysis, H.W. and P.W.; investigation, D.L.; writing - original draft preparation, H.W.; writing—review and editing, D.L.; project administration, D.L.; funding acquisition, D.L. All authors have read and agreed to the published version of the manuscript.

Funding: This research was supported by the National Natural Science Foundation of China (No. 71772055), Humanities and Social Sciences of Ministry of Education Planning Fund of China (No. 17YJA630067), Fundamental Research Funds for the Central Universities (No. JZ2019HGTB0094), and Anhui Philosophical and Social Science Program (No. AHSKY2019D030).

Data Availability Statement: The data presented in this study are available on request from the corresponding author. The data are not publicly available due to privacy. 
Acknowledgments: The authors would like to thank The Research Center of Entrepreneurship of Nankai University for supporting the Chinese Panel Study of Entrepreneurial Dynamics (CPSED). We would also like to thank the reviewers for their valuable comments. Gratitude is also extended to all authors of the literature cited in this article.

Conflicts of Interest: The authors declare no conflict of interest.

\section{References}

1. Shane, S.; Venkataraman, S. The Promise of Entrepreneurship as a Field of Research. Acad. Manag. Rev. 2000, 25, 217-226. [CrossRef]

2. Busenitz, L.W.; Plummer, L.A.; Klotz, A.C.; Shahzad, A.; Rhoads, K. Entrepreneurship Research (1985-2009) and the Emergence of Opportunities. Entrep. Theory Pract. 2014, 38, 981-1000. [CrossRef]

3. Franco, M.; Haase, H. Failure factors in small and medium-sized enterprises: Qualitative study from an attributional perspective. Int. Entrep. Manag. J. 2009, 6, 503-521. [CrossRef]

4. Long, D.; Xia, Z.; Hu, W. How does entrepreneurial opportunity affect the decision-making process of effectuation? Kybernetes 2017, 46, 980-999. [CrossRef]

5. Sarasvathy, S.D. Effectuation Elements of Entrepreneurial Expertise; Edward Elgar Publishing: Cheltenham, UK, 2008.

6. Sarasvathy, S.D. Causation and effectuation: Toward a theoretical shift from economic inevitability to entrepreneurial contingency. Acad. Manag. Rev. 2001, 26, 243-263. [CrossRef]

7. Brettel, M.; Mauer, R.; Engelen, A.; Küpper, D. Corporate effectuation: Entrepreneurial action and its impact on R\&D project performance. J. Bus. Ventur. 2012, 27, 167-184.

8. Arend, R.J.; Sarooghi, H.; Burkemper, A. Effectuation as ineffectual? Applying the 3E theory-assessment framework to a proposed new theory of entrepreneurship. Acad. Manag. Rev. 2015, 40, 630-651. [CrossRef]

9. Dew, N.; Read, S.; Sarasvathy, S.D.; Wiltbank, R. Effectual versus predictive logics in entrepreneurial decision-making: Differences between experts and novices. J. Bus. Ventur. 2009, 24, 287-309. [CrossRef]

10. Read, S.; Sarasvathy, S. Knowing what to do and doing what you know: Effectuation as a form of entrepreneurial expertise. J. Priv. Equity 2005, 9, 45-62. [CrossRef]

11. Wiltbank, R.; Dew, N.; Read, S.; Sarasvathy, S.D. What to do next? The case for non-predictive strategy. Strateg. Manag. J. 2006, 27, 981-998. [CrossRef]

12. Read, S.; Song, M.; Smit, W. A meta-analytic review of effectuation and venture performance. J. Bus. Ventur. 2009, $24,573-587$. [CrossRef]

13. Mauer, R.; Smit, W.; Forster, W.; York, J. Curry in a hurry? A longitudinal study on the acceleration of performance through effectuation by nascent entrepreneurs (Summary). Front. Entrep. Res. 2010, 30, 13.

14. Garonne, C.; Davidsson, P.; Steffens, P. Do strategy choices matter for nascent firms? A study on effectuation and causation impacts on new ventures outcomes. In Proceedings of the 7th AGSE International Entrepreneurship Research Exchange, Queensland, Australia, 2-5 February 2010; pp. 325-336.

15. Roach, D.C.; Ryman, J.A.; Makani, J. Effectuation, innovation and performance in SMEs: An empirical study. Eur. J. Innov. Manag. 2016, 19, 214-238. [CrossRef]

16. Smolka, K.M.; Verheul, I.; Burmeister-Lamp, K.; Heugens, P.P.M.A.R. Get it Together! Synergistic Effects of Causal and Effectual Decision-Making Logics on Venture Performance. Entrep. Theory Pract. 2018, 42, 571-604. [CrossRef]

17. Reymena, I.; Andries, P.; Berendsd, H. Understanding dynamics of strategic decision-making in venture creation: A process study of effectuation and causation. Strateg. Entrep. J. 2015, 9, 351-379. [CrossRef]

18. Burks, A.W. Chance, Cause, Reason. J. Am. Stat. Assoc. 1979, 74, 502-503.

19. Simon, H.A. Theories of Decision-Making in Economics and Behavioral Science. Am. Econ. Rev. 1959, 49, $253-283$.

20. Sarasvathy, S.D.; Venkataraman, S. Entrepreneurship as Method: Open Questions for an Entrepreneurial Future. Entrep. Theory Pract. 2011, 35, 113-135. [CrossRef]

21. Chandler, G.N.; Detienne, D.; Mumford, T.V. Causation and Effectuation: Measurement Development and Validation. Front. Entrep. Res. 2017, 27, 3.

22. Chandler, G.N.; DeTienne, D.R.; McKelvie, A.; Mumford, T.V. Causation and effectuation processes: A validation study. J. Bus. Ventur. 2011, 26, 375-390. [CrossRef]

23. Forster, W.R.; York, J.G. The effects of effectual logic: Nascent entrepreneurial performance and effectuation. Front. Entrep. Res. 2008, 28, 4 .

24. McKelvie, A.; DeTienne, D.R.; Chandler, G.N. What is the appropriate dependent variable in effectuation research? Front. Entrep. Res. 2013, 33, 1-16.

25. Urban, B.; Heydenrych, J. Technology Orientation and Effectuation-Links to Firm Performance in the Renewable Energy Sector of South Africa. S. Afr. J. Ind. Eng. 2015, 26, 125-136. [CrossRef]

26. Cai, L.; Guo, R.; Fei, Y.; Liu, Z. Effectuation, Exploratory Learning and New Venture Performance: Evidence from China. J. Small Bus. Manag. 2017, 55, 388-403. [CrossRef]

27. Szambelan, S.; Jiang, Y.; Mauer, R. Breaking through innovation barriers: Linking effectuation orientation to innovation performance. Eur. Manag. J. 2019, 38, 425-434. [CrossRef] 
28. Kraaijenbrink, J.; Ratinho, T.; Groen, A. Planning effectual growth: A study of effectuations and causation in nascent firms. In Proceedings of the Babson College Entrepreneurship Research Conference, Syracuse, NY, USA, 8-11 June 2011.

29. Guo, R.; Cai, L.; Zhang, W. Effectuation and causation in new internet venture growth. Internet Res. 2016, 26, 460-483. [CrossRef]

30. Laskovaia, A.; Shirokova, G.; Morris, M.H. National culture, effectuation, and new venture performance: Global evidence from student entrepreneurs. Small Bus. Econ. 2017, 49, 687-709. [CrossRef]

31. Welter, C.; Kim, S. Effectuation under risk and uncertainty: A simulation model. J. Bus. Ventur. 2018, 33, 100-116. [CrossRef]

32. Futterer, F.; Schmidt, J.; Heidenreich, S. Effectuation or causation as the key to corporate venture success? Investigating effects of entrepreneurial behaviors on business model innovation and venture performance. Long Range Plan. 2018, 51, 64-81. [CrossRef]

33. Vanderstraeten, J.; Hermans, J.; Witteloostuijn, A.V.; Dejardin, M. SME innovativeness in a dynamic environment: Is there any value in combining causation and effectuation? Technol. Anal. Strateg. Manag. 2020, 32, 1277-1293. [CrossRef]

34. Cash, D.W.; Clark, W.C.; Alcock, F. Knowledge systems for sustainable development. Proc. Natl. Acad. Sci. USA 2003, 100, 8086-8091. [CrossRef]

35. Beaumont, J.R. Changing Course: A Global Business Perspective on Development and the Environment; The MIT Press: Cambridge, UK, 1993.

36. Jeurissen, R. John Elkington, Cannibals with Forks: The Triple Bottom Line of 21st Century Business. J. Bus. Ethics 2000, 23, 229-231. [CrossRef]

37. Salzmann, O.; Ionescu-Somers, A.; Steger, U. The Business Case for Corporate Sustainability. Eur. Manag. J. 2005, 23, 27-36. [CrossRef]

38. Zhang, H.; Wang, Y.; Song, M. Does Competitive Intensity Moderate the Relationships between Sustainable Capabilities and Sustainable Organizational Performance in New Ventures? Sustainability 2019, 12, 253. [CrossRef]

39. Rahman, M.; Mendy, J. Evaluating people-related resilience and non-resilience barriers of SMEs' internationalisation. Int. J. Organ. Anal. 2019, 27, 225-240. [CrossRef]

40. Lessmann, O.; Rauschmayer, F. Re-conceptualizing Sustainable Development on the Basis of the Capability Approach: A Model and Its Difficulties. J. Hum. Dev. Capab. 2013, 14, 95-114. [CrossRef]

41. Banker, R.D.; Mashruwala, R.; Tripathy, A. Does a differentiation strategy lead to more sustainable financial performance than a cost leadership strategy? Manag. Decis. 2014, 52, 872-896. [CrossRef]

42. Teng, J.; Mu, X.; Wang, W.; Xu, C.; Liu, W. Strategies for sustainable development of green buildings. Sustain. Cities Soc. 2019, 44, 215-226. [CrossRef]

43. Igwe, P.A.; Odunukan, K.; Rahman, M.; Rugara, D.G.; Ochinanwata, C. How entrepreneurship ecosystem influences the development of frugal innovation and informal entrepreneurship. Thunderbird Int. Bus. Rev. 2020, 62, 475-488. [CrossRef]

44. Ma, L.; Cao, Y.; Jiang, D.; Gao, Y.; Du, X. Does ethics really matter to the sustainability of new ventures? The relationship between entrepreneurial ethics, firm visibility and entrepreneurial performance. PLoS ONE 2020, 15, e0226920. [CrossRef]

45. Asif, M.; Searcy, C.; Zutshi, A.; Fisscher, O.A.M. An integrated management systems approach to corporate social responsibility. J. Clean Prod. 2013, 56, 7-17. [CrossRef]

46. Suganthi, L. Investigating the relationship between corporate social responsibility and market, cost and environmental performance for sustainable business. S. Afr. J. Bus. Manag. 2020, 51, 1-13.

47. Nurunnabi, M.; Esquer, J.; Munguia, N.; Zepeda, D.; Perez, R.; Velazquez, L. Reaching the sustainable development goals 2030: Energy efficiency as an approach to corporate social responsibility (CSR). GeoJournal 2019, 85, 363-374. [CrossRef]

48. Jiang, Y.; Tornikoski, E.T. Perceived uncertainty and behavioral logic: Temporality and unanticipated consequences in the new venture creation process. J. Bus. Ventur. 2019, 34, 23-40. [CrossRef]

49. Porter, M.E. Competitive Strategy: Techniques for Analyzing Industries and Competitors. South Asian J. Manag. 1980, 20, 194-199.

50. Bhide, A. How Entrepreneurs Craft Strategies That Work. Harv. Bus. Rev. 1994, 72, 150-161.

51. Hahn, T.; Figge, F.; Pinkse, J.; Preuss, L. Trade-Offs in corporate sustainability: You cannot have your cake and eat it. Bus. Strateg. Environ. 2010, 19, 217-229. [CrossRef]

52. Zimmerman, M.A.; Zeitz, G.I. Beyond survival: Achieving new venture growth by building legitimacy. Acad. Manag. Rev. 2002, 27, 414-431. [CrossRef]

53. Singh, J.V.; Tucker, D.J.; House, R.J. Organizational legitimacy and the liability of newness. Adm. Sci. Q. 1986, 31, 171-193. [CrossRef]

54. Galkina, T.; Chetty, S. Effectuation and Networking of Internationalizing SMEs. Manag. Int. Rev. 2015, 55, 647-676. [CrossRef]

55. An, W.; Rüling, C.-C.; Zheng, X.; Zhang, J. Configurations of effectuation, causation, and bricolage: Implications for firm growth paths. Small Bus. Econ. 2019, 54, 843-864. [CrossRef]

56. Wind, Y.; Robert, J.T. Organizational Buying Behavior in an Interdependent World. J. Glob. Acad. Mark. Sci. 2010, 20, 110-122. [CrossRef]

57. Eijdenberg, E.L.; Paas, L.J.; Masurel, E. Decision-making and small business growth in Burundi. J. Entrep. Emerg. Econ. 2017, 9, 35-64. [CrossRef]

58. Sharu, H.; Guyo, D.W. Factors influencing growth of youth owned small and medium enterprises in Nairobi County, Kenya. Int. J. Sci. Res. 2015, 4, 973-987. 
59. Chandler, G.N.; Hanks, S.H. Founder Competence, the Environment, and Venture Performance. Entrep. Theory Pract. 1994, 18, 77-89. [CrossRef]

60. Schick, H.; Marxen, S.; Freimann, J. Sustainability Issues for Start-up Entrepreneurs. Greener Manag. Int. 2002, 38, 59-70. [CrossRef] 